\title{
Lemons into lemonade
}

\author{
A booming economy can make layoffs in the biotechnology industry \\ a blessing in disguise.
}

Daniel Coulter

Tina Tedder had worked as a research associate at La Jolla Pharmaceutical (San Diego, CA) for four years. On Tuesday afternoon, September 14, 1999, the company announced there would be layoffs. Later that day, Tedder learned that she would be out of work by the end of the week.

Tedder says most employees at La Jolla Pharmaceutical figured layoffs were imminent. In May that year, the company ended phase II/III clinical trials of its lead product candidate, for the treatment of lupus, prematurely after what appeared to be disappointing results. Employees correctly presumed the company would have to let some people go to save money. In October, exactly one month later, Tedder resumed working as a research associate at another drug discovery company in San Diego that pays 20\% more than her previous job.

Others have found similar fortune amid misfortune. Richard Lin, a researcher formerly with Axys Pharmaceuticals, says layoffs at his company were a complete surprise. Axys decided to trim a large portion of its San Diego operations and offered to relocate employees to its headquarters in South San Francisco. Not wanting to relocate, Lin found a new position six weeks later where he enjoys increased responsibility and greater pay. Lin says most people in entry and mid-level positions fared well, though some of his senior-level colleagues have had a harder time finding a desired position.

\section{Moving on and up}

Layoffs seem inevitable in small drug-discovery companies, often because firms are cashstrapped and their future hinges on one agreement, technology, or product succeeding. Demand for skilled chemists, biologists, and others remains high due to the booming economy, the growth of existing firms, and the creation of many new start-ups.

Though layoffs are no fun for the employees affected, they are ultimately healthy for the industry: Downsizing allows companies to conserve cash and direct it to

Daniel Coulter is a research associate at $L G$ Biomedical Institute, 3252 Holiday Court, Suite 101, La Jolla, CA 92037 (dcoulter@mail.lgbmi.com). other areas that may assist in the company's survival. For those who are laid-off who choose to remain in the industry, layoffs give them an opportunity to broaden their skill sets and gain exposure to new environments at other companies. Overall, the industry benefits from both fiscally sound firms and an experienced, cross-trained workforce. And fortunately, in today's mar-

\section{Layoffs seem inevitable in small drug-discovery com- panies, but demand for skilled chemists, biologists, and others remains high due to the booming econo- my, the growth of existing firms, and the creation of many new start-ups.}

ketplace, just as Tedder and Lin discovered, layoffs may paradoxically increase your income.

\section{Networking strategies}

If you're concerned about layoffs, or know you will be changing jobs in the near future, the following is a checklist of items to keep in mind. Some of these may be obvious, but all are proven strategies for finding out where the jobs are and whom to approach.

While employed, get to know as many people in your field as you can. Don't limit your network to just the research side of the industry-get acquainted with supervisors and business managers, the people with the authority to hire and those most likely to know of openings. Do this at all levels: within your company, in your city or region, and at national meetings.

Keep in contact with this network of old and new acquaintances via e-mail, phone calls, holiday cards, and occasionally inviting them to lunch or getting together at industry conferences. Just as one never knows where a promising job lead may come from, one never knows what promising leads a helpful network can steer your way. Career experts say that most of the best jobs are filled through this internal and informal grapevine of information and recommendation.

Update your résumé with projects you've completed and those that are on-going. Include new techniques, software, and instrumentation you've used, as well as recent classes and short courses taken, conferences attended, or training received.

Contact supervisors, co-workers, and others about providing a reference for you. Provide them with your résumé and any items you'd like them to focus on in a letter of recommendation or in a phone conversation from a potential employer.

Start bookmarking industry, career, and company websites you know you'll want to visit in the weeks ahead.

\section{Conclusions}

Take advantage of the booming economy and its benefits while it is here. No one knows how long it will last, nor how long or severe the next recession may be. Even if you're not looking for a new position, it may be helpful and informative to interview casually with other companies to learn about the current job market and your own market value, in addition to keeping your interviewing and job-hunting skills sharp. You might find you really like the company you visit, or they may present a fabulous offer you would seriously regret passing up. If your company downsizes in the future, or announces a wage freeze, an offer from another company is good insurance to have.

As a final safeguard, be sure to understand your work contract and benefits package, especially severance pay benefits and unemployment benefits. Should you obtain a new position, carefully negotiate your salary and benefits package. Never take the first offer. As a potential new hire, you have a small, fixed window in which to negotiate what you want: salary, flexible working hours, vacation and sick days, telecommuting options, moving expenses, starting bonus, etc. Once you accept the offer, your power and negotiating flexibility are greatly diminished.

\footnotetext{
Further reading

1. Chapman, J. Negotiating Your Salary: How to Make $\$ 1000$ A Minute (Ten Speed Press, Berkeley, CA; 1996).

2. 2000 Career Guide, US News \& World Report, November 1, 1999.
} 